\title{
The Soviet Union and Cyprus in 1974 Events
}

\author{
By Ilksoy Aslım*
}

The Cypriot-Russian relations are generally perceived as excellent. However, as some primary sources show the Soviet Union (SU) could/did not act as an "excellent friend" during the military attack of Turkey towards Cyprus in 1974. The aim of this paper is to examine the background and the reasons of the failure of the SU in helping Cyprus during 1974. The constraints of the SU on Cyprus were its connections with Turkey and the United States (US). The SU started rapprochement with Turkey and détente with the US before the 1974 events and these developments have changed their relations dramatically. The SU and the US had to prevent any conflict on Cyprus from complicating their relations. Consequently during the Greek coup and military attack of Turkey, they did not take any initiative because of the existing balance between them. The SU was an observer during the events and aimed to secure the "existing Constitution".

\section{Introduction}

After World War II, the Soviet Union and the United States emerged as the two chief powers of the globe. As the SU increased its influence in Eastern Europe the US perceived it as an expansionist policy and aimed at containing the Soviets in Eastern Europe and elsewhere. The term "containment" referred to a specific US policy of containing the SU. For the US, there was the unity of communist theory and practice, i.e. communism was directed from one center (Moscow) and the US had a moral duty to struggle against communism. ${ }^{1}$ In order to reach these goals, the US firstly declared the Truman Doctrine and Marshall Plan; secondly, prepared the North Atlantic Treaty; and thirdly, constructed the organizational mechanisms of NATO. The SU on the other hand to challenge the US containment established the Council for Mutual Economic Assistance (COMECON) and the Warsaw Pact. The SU justified its policies by claiming that it was responding the encirclement of the capitalist bloc. ${ }^{2}$

Both the SU and the US designed their foreign policies in the Eastern Mediterranean in accordance to their global policies. In 1952, Turkey and Greece became two new members of NATO and received responsibility as parts of the "Northern Tier zone" which covered the area from the Balkans to Central Asia confronting the Soviet Union. In this regard, crisis and disputes arising in the internal relations between these countries were welcomed by the Soviet Union. Moscow's strategy was recruiting the member countries of the anti-communist alliances and bringing to the Non-Aligned countries; thus

\footnotetext{
${ }^{*}$ Lecturer \& Chairperson, Near East University, Cyprus.

1. C. O. Lerche, "The Crisis in American World Leadership," The Journal of Politics, 28, no. 2 (1966): 309-310. In the late 1960's the assumption that communism was controlled from one center changed with the split of the communist camp into two, between the Soviet Union and Communist China.

2. O. Sander, Türk-Amerikan Ilişkileri (1947-1964) [Turkish-American Relations (19471964)] (Ankara: Ankara Üniversitesi Siyasal Bilgiler Fakültesi Yayınları, 1979), 12.
} 
extending Soviet power and influence over the Eastern Mediterranean ${ }^{3}$, the area that Cyprus has also been placed.

\section{Changes in the Soviet Foreign Policy after Stalin}

After the death of Stalin, the Soviet foreign policy changed and its influence in the oil-rich Middle East increased when the regimes of Egypt, Iraq, and Syria changed and nationalist, anti-American elements came to power. The first wave of Soviet penetration to the Middle East was indirectly realized by Czechoslovakia, a member of the Warsaw Pact. The years after 1955 saw a rising tide of Arab nationalism sweep through the Middle East and the Egyptian President Gamal Abdul Nasser signed an agreement of delivery of Czechoslovakian weapons in $1955 .{ }^{4}$ With this agreement the region turned into a battleground of the Cold War and the SU was inside the US sphere of interest. In this context, Cyprus also became part of an arena in the Cold War competition.

In order to be familiar with the Soviet foreign policy we have to look at the changes after the death of Joseph Stalin in 1953. The SU foreign policy began to change with the critiques on Stalin during the Twentieth Congress of the Communist Party of the Soviet Union in $1956 .{ }^{5}$ Tellal summarized the changes in Soviet policy as following: The new policy was the rejection of Stalin's policy which saw "everybody who does not support the Soviet Union as an enemy". This was also the rejection of the "two camps theory" of Stalin claiming "war between the two camps is inevitable". Secondly, it was the reflection of Soviet self-confidence as their technological prowess having reached the same level as the West. Thirdly, the Soviets perceived the independence of new nations as a positive trend against the West. ${ }^{6}$ The policy of peaceful coexistence was based on the understanding of the fact that a nuclear war would destroy both parties. Hence, the SU began to behave like a "world state". After the Soviet Communist Party Congress decision that two different political and economic systems could be in peaceful coexistence, the Soviets' friendship with non-communist states became possible.

\section{Cyprus: An Arena of the Cold War}

With the London and Zurich agreements the British kept two military bases in the island and transferred its sovereignty to the Republic of Cyprus. During this period, the US was the mediator between Turkey and Greece, the

3. A. Stergiou, "Soviet Policy toward Cyprus," The Cyprus Review 19, no. 2 (2007): 83.

4. J. A. Combs, The History of American Foreign Policy Since 1900, Vol. II (New York: McGraw-Hill Publication Company, 1986), 357-364.

5. N. Khrushchev, Speech to 20th Congress of the C.P.S.U., 24-25.02.1956, accessed October 2, 2015, http://bit.ly/1P13XiY.

6. E. Tellal, "Relations with the USSR," in Turkish Foreign Policy: Facts and Analyses with Documents, ed. B. Oran (Salt Lake City: The University of Utah Press, 2010), 304. 
"motherlands" of the Turkish and Greek Cypriots in the island. However, the legalization of the Cyprus Communist Party, AKEL was not prevented by the Greek Cypriot leader Archbishop Makarios and the British Governor because of belief that the communists should be defeated openly rather than by suppression. Of course this was an advantage for the SU in operating its policy in Cyprus.

When the intercommunal conflict aroused between the Greek and Turkish Cypriots in the island in 1964 the SU aimed to use the dispute to extend its influence in the region. On the other hand, the US expected that two guarantor states of the Republic, Greece and Turkey, would agree on a solution and the parties in Cyprus would comply. However, Cypriot President Makarios' relations with the Non-Aligned countries and the SU gave him relative freedom of action. The membership of the Non-Alignment Movement has meant getting support of the Soviet Union and having relative freedom of action inside the sphere of influence of the US. Hence, although close relations between the Soviets and Makarios continued, Cypriots were perceived to be a part of the Western world.

In the following years the SU supported AKEL and the communist trade union, PEO. The US, UK, Greece and Turkey on the side sought to maintain a pro-Western outlook on Cyprus and to prevent the Cypriots establishing excessive economic ties with the Sino-Soviet bloc. In this context, the US tried to strengthen non-communist labor organizations and to prohibit AKEL. On one side the US tried to organize the new republic with the help of the guarantors and on the other side the SU tried to increase its influence especially on the Greek Cypriots. The competition was in all areas. One of the first telegrams of the US Ambassador Wilkins to the Department of State was requesting aid to Cyprus because the communists were working on farmers and the Soviet Ambassador in Athens had visited Cyprus and promised aid. ${ }^{7}$

\section{The Soviet Union and Cyprus after 1960}

The Soviet diplomacy towards the island was initially designed through the UN. In the 1950s the SU and its allies supported Greece's efforts to internationalize the Cyprus issue in the UN. The SU was trying to hinder a NATO-inspired settlement of the problem which might have enhanced the influence of the West in the region as well as to exploit and escalate possible tensions in it.

When the Greek and the Turkish Cypriot nationalists sought to change the status quo (uniting the island with Greece or partition the island), civil war started in the island in December 1963. The London Conference that was organized to solve the issue was condemned by the SU as being a NATO plot. The Soviets' statement warned the West not to interfere in the domestic issues of Cyprus and stressed that safeguarding the independence of Cyprus was the

7. F. Wilkins, Telegram from the Embassy in Nicosia to the Department of State, September 28, 1960, accessed May 21, 2016, http://1.usa.gov/1YQXyZx. 
task of the Security Council. ${ }^{8}$ The Soviets continuously claimed that the imperialist powers interfere in the internal affairs of Cyprus "to steer the republic away from its neutralist stand and bring it under NATO military and political control". ${ }^{9}$ President Makarios did not accept what has offered in London and preferred to apply to the UN to seek a solution in Cyprus. ${ }^{10}$ Now the Cyprus problem was internationalized through the UN, an arena that the SU was in.

In the years following years AKEL had become the strongest party on the island. Many members of AKEL got a special scholarship and studied in communist countries and later received important tasks in the party. During the 1963-1964 events the SU, German Democratic Republic (GDR) and Czechoslovakia showed solidarity to Cyprus. While GDR has given political support, Czechoslovakia was responsible to organize selling weapons to the island. $^{11}$

The Security Council resolution of March 4, 1964 was a compromised solution between East and West and the UN force that recruited for Cyprus peace as neither from the NATO nor from the Warsaw Pact. The solution was in favor of the SU because integrity of the Republic of Cyprus has continued. Also it ended the possible war between Turkey and Greece, a gain for the US.

\section{Soviet Union and Turkey's Rapprochement and Arms Crises}

In 1964 the Soviet Union has reached a critical decision to start TurkishSoviet rapprochement. According to the Soviets, the Turkish-Soviet rapprochement, in some ways, could weaken the Southeastern wing of NATO and might decrease Turkish hostility towards the SU. Moreover, the SU opposed Enosis because it would "bring Cyprus automatically into NATO and weaken [the] position [of the] Cypriot Communist Party". ${ }^{12}$ Clearly, the Turkish-Soviet rapprochement had several advantages for the Soviet Union.

For the West, the Soviet objective was clear. It sought an atmosphere where Turkey bloc Enosis, to strengthen its leverage in Cyprus and to neutralize Enosis and Soviet support for Makarios. Yet, the US-Turkey connection and Turkey's cohesion with the West was so deep that Turkish rapprochement with the SU could not challenge it. ${ }^{13}$ With this move Turkey

8. Rusk, Telegram from the Department of State to the Embassy in Nicosia (384), January 31, 1964, POL 23-8 CYP, box 2078, NARA.

9. A.A. Gromyko and V. Mikhailovich Khvostov, History of Soviet Foreign Policy (19451970) (Moscow: Progress Publishers, 1974), 353.

10. M. M. Fırat, 1960-71 Arası Türk Dış Politikası ve Kıbrıs Sorunu [Turkish Foreign Policy and Cyprus Problem between 1960 and 1971] (Ankara: Siyasal Kitabevi, 1997), 127. 91

11. A. Stergiou, "Soviet Policy toward Cyprus," The Cyprus Review 19, no. 2 (2007): 89-

12. Kohler, Telegram from the Embassy in Moscow to the Department of State 2287, February 6, 1965: POL 27 CYP, box 2095, NARA.

13. E. Talbot, Memorandum from the Embassy in Athens to the Department of State (Ball), "Review of U.S. Cyprus Policy", December 31, 1964: POL 27 CYP, box 2094, NARA. 
sought to avoid its regular defeats at the UN as well. The US did not cause disturbance because its main concern about independence was Makarios' leaning towards the Soviet bloc. However, this could not be a threat anymore because of the Turkish-Soviet rapprochement and the close relations of Turkey with the US. ${ }^{14}$

The SU-Turkey rapprochement however did not stop its Cyprus connection. In the eyes of the Americans, the SU was a real threat of making Cyprus a "Mediterranean Cuba. The import of heavy arms of Cyprus from the United Arab Republic (UAR) ${ }^{15}$ was seen as a communist conspiracy by the West to enter the island issue. The report of the US Ambassador on May 22, 1964 informed the State Department that the UAR would be the principal source, but the Soviets would finance the deal. ${ }^{16}$ As the US saw the arms import an effort of the SU to increase its influence on the island immediately opposed the arms trade. ${ }^{17}$ After strong US pressure the Greeks were successful in incepting the ship carrying the arms to Cyprus and returned it to Egypt. In return, Turkey gave its assurance that it would not intervene. ${ }^{18}$

Another Cold War strain happened in November 1966 when heavy arms had arrived to Cyprus from Czechoslovakia. ${ }^{19}$ Turkey was diplomatically very active and upon its urgent request Czechoslovakia stopped a second shipment. ${ }^{20}$ Turkey announced that it would undertake "extremely grave counter-measures if the arms were not sterilized." 21 The US, in order to save the dialogue between Turkey and Greece put heavy pressure on the Greek Government to urge Makarios to store the arms under the control of the Greek Army in Cyprus. ${ }^{22}$ In spite of the Cold War, both the Soviets and the

14. As Bolukbasi writes, starting from autumn 1964, the Cyprus policy of the Soviet Union "resembled a juggling act in which the Soviets did not want to offend any of the parties." S. Bolukbasi, The Superpowers and the Third World: Turkish American Relations and Cyprus (Langham: University Press of America, 1988), 118.

15. The United Arab Republic (UAR) was a union between Egypt and Syria. The Union was concluded in 1958 and it existed until 1961. Egypt continued to be known officially as the "United Arab Republic" until 1971 when it took the name Arab Republic of Egypt. Encyclopadia Britannica Online, s. v. "United Arab Republic (U.A.R.)", accessed February 6, 2016, http://bit.ly/1U3ZmKi.

16. Belcher, Telegram from the Embassy in Nicosia to the Department of State 1265 , May 22, 1964: POL 23-8 CYP, box 2084, NARA.

17. Rusk, Telegram from the Department of State to the Embassy in Nicosia 860, May 20, 1964: POL 23-8 CYP, box 2084, NARA.

18. Rusk, Telegram from the Department of State to the Embassy in Athens 1179, March 18, 1965: POL 27 CYP, box 2096, NARA.

19. N. Katzenbach, Telegram from the Department of State to the Embassy in Paris 104909, December 19, 1966: POL 27 CYP, box 2100, NARA.

20. Belcher reported later in: Airgram from the Embassy in Nicosia to the Department of State A-249, June 2, 1967: POL 1 CYP-US, box 2029, NARA. Also see: M. M. Firat, 1960-71 Arası Türk Dış Politikası ve Kıbrıs Sorunu [Turkish Foreign Policy and Cyprus Problem between 1960 and 1971] (Ankara: Siyasal Kitabevi, 1997), 219.

21. E. Talbot, Telegram from the Embassy in Athens to the Department of State 3093, December 16, 1966: POL 27 CYP, box 2100, NARA.

22. N. Katzenbach, Telegram from the Department of State to the Embassy in Athens 101135, 12.12.1966: POL 27 CYP XR DEF 19-6 CZECH-CYP, box 2100, NARA; N. 
Americans opposed Makarios' act. In 1966 Soviet Prime Minister Aleksei Kosygin paid a visit to Turkey and supported the Turkish position while criticizing the Greek Cypriots. Moreover, Kosygin surprisingly condemned Soviet ally Czechoslovakia because of the arms delivery. ${ }^{23}$ The visit can be seen as the reflection of the Soviet intention to continue the Soviet-Turkish rapprochement.

In 1967 two events shaped the politics of Greece and Cyprus. The army made a coup against the Greek government and Grivas, the Commander of the National Guard and also of the Greek Armed Forces in Cyprus, ordered an attack to the two Turkish Cypriots villages. The SU has blamed the anticommunist junta for its acts in Greece and in Cyprus during the crisis. However, when the Soviets aimed on improving relations with Turkey the consequence was losing its leverage over President Makarios. ${ }^{24}$ Yet, it can be said that the position of the Soviets during the crisis was "a rather distant observer role." ${ }^{25}$ The main aim of the SU during the crisis was to assure the independence of Cyprus and prevent the NATO countries to get the control of Cyprus. The Soviets seemed reluctantly to agree on an independent Cyprus in the sphere of interests of the US. The rules of the Cold War continued to be settled and neither of the superpowers would interfere in the domestic (and in the settled spheres of interest) affairs of the other party. Now the Cypriot Communist Party was tamed and did not seek a change in the status quo and Cyprus issue was seen as a domestic problem of the United States.

\section{Détente Policy and its Effects to Cyprus}

Détente is a diplomatic term meaning a relaxation or a slackening of tension in the previously strained relation between states. It's a shift from doctrinaire confrontational policies of the 1950s to the more flexible diplomacy of the 1960s and 1970s. ${ }^{26}$ Another explanation of détente refers to periods of reduced tension in relations between the United States and the Soviet Union

Katzenbach, Telegram from the Department of State to the Embassy in Paris 98890, December 8, 1966: DEF 12-5 CYP, box 1620, NARA.

23. The core story of the process and consequences of the Czech arms is in: Rusk, Telegram from the Department of State to the Embassy in Ankara 143499, February 24, 1967: POL 27 CYP XR DEF 19-6 CZECH-CYP, box 2023, NARA; Belcher, Telegram from the Embassy in Nicosia to the Department of State 1249, February 24, 1967: POL 27 CYP, box 2023, NARA; T. W. Adams and A. J. Cottrell, Cyprus between East and West (Baltimore: The John Hopkins Press, 1968), 47.

24. Hughes, Memorandum for the Cyprus Working Group, "Contingency Planning on Cyprus-Assessment of Likely Soviet Action", November 22, 1967: Lot 70D46, Entry 5191, Office of the Executive Secretariat: Cyprus Crisis Files, 1967: Working Papers, box 3, NARA.

25. Hughes, Intelligence Note to Rusk, "Soviet Government Criticizes Athens and Greek Cypriot Regimes, Is Soft on Turks", November 22, 1967: POL 27 CYP, box 2025, NARA.

26. G. Evans and J. Newnham, Dictionary of International Relations (London: Penguin Books, 1998), 125. 
during the Cold War. It was associated with the process and progress of arms control. $^{27}$

In September 1973 Soviet leader Leonid Brezhnev repeated his views on détente. For him, the goal of the détente was peaceful cooperation with the Western countries. ${ }^{28}$ The SU Foreign Minister Andrei A. Gromyko considered détente as going "further than good wishes and verbal assurances." For him, it has become possible to reduce the risk of an armed conflict between the social systems by the agreements of 1972-1974 between the SU and the US. ${ }^{29}$ For Tellal détente was a must for the SU because of two reasons: Nuclear balance and technological revolution of science; while class struggle policy of the Soviets has continued, it was the way to pass to socialism in a peaceful way. ${ }^{30}$

The US also realized the changes in the world and its foreign policy has changed in 1970. In August 1970, a briefing paper of the State Department explained the new look of the US foreign policy. According to the paper, there was "growing interdependence of nations." The US pointed out the evolution of its relations with the SU "from one of strategic superiority to one of strategic parity." It had become possible for the US and the SU, through dialogue and experience with nuclear deterrence, to identify common interests and create some sort of rules of behavior. ${ }^{31}$ Actually, the President's Report to the Congress in February 1970 had given the key aspects of partnership and search for a broader share of responsibility. The results were the nuclear nonproliferation treaty and the SALT talks. Of course, the new course of the US required reducing tension in areas which could lead to great power conflict. ${ }^{32}$ Consequently, ideology-dominated policies changed and the SU and the US became more pragmatic. Now détente factor has dominated their foreign policies.

Détente produced several outcomes for the SU. The first outcome was acceptance of the Soviet strategic parity. The second one was the chance to limit the arm race and thus reallocate investment to civilian economy. The third outcome was to put an end to the East-West crisis in Europe and a shift of competition to the Third World. The fourth one was easing the tensions on the SU's western flank, and to concentrate on China. The fifth outcome was the

27. I. McLean, The Concise Oxford Dictionary of Politics (Oxford: Oxford University Press, 1996), 136.

28. L. Breznev, "The USSR's Foreign Policy: Peace is Indivisible," Vital Speeches of the Day, Speach delivered at Tashkent, September 25, 1973.

29. A. A. Gromyko, Arms Limitation and Other Treaties, Vital Speeches of the Day, Speach Delivered before the General assembly of the United Nations, September 24, 1974.

30. E. Tellal, "Sovyet Dış Politikası ve Gromiko" ["Soviet Foreign Policy and Gromyko"], Ankara Universitesi SBF Dergisi, 62 no. 3 (2007): 360.

31. Paper prepared by the Planning and Coordination Staff at the State Department: Briefing for the Under Secretary: "Foreign Affairs Policies and Problems", August 28, 1970: Executive Secretariat Briefing Books, 1958-1976, Lot 72D170 Committee to Facil Travel, 5/1970, box 49, NARA.

32. H. W. Brands, The United States in the World: A History of American Foreign Policy, Vol. II (Boston: Houghton Mifflin Company, 1994), 124-125. Kissinger explains that in the Middle East the aim was also to reduce the Soviet influence. See also H. A. Kissinger, Diplomacy (New York, etc: Touchstone-Simon \& Schuster, 1995), 737. 
recognition of Eastern Europe's postwar frontiers. The last outcome of the Soviet's was the opportunity to increase imports of goods, technology, and capital from the West. ${ }^{33}$

After détente both the SU and the US preferred a quiet and stable Cyprus where the status quo was preserved and Greece and Turkey were not on the brink of war. The US assured the Soviet Ambassador Anatoly Dobrynin that its position on Cyprus was to monitor the events there closely and to encourage Athens and Ankara to continue their positive approach to the Cyprus problem. ${ }^{34}$ The Czech Arms Crisis in 1972 did not produce much tension between the SU and the US and the State Department reminded their Embassies not to exaggerate the Communist threat in Cyprus. ${ }^{35}$ Like the SU, the US supported "peaceful negotiations [...] within the context of an independent, sovereign and territorially whole Cyprus." ${ }^{36}$

On a wider scope, SU-US rapprochement was again in high gear and they did not want the crises in the Middle East and in Cyprus to complicate their evolving relations. ${ }^{37}$ More importantly, for the first time, the State Department saw the Cyprus conflict as having "the potential to complicate [its] evolving relations with the Soviets and affect the atmosphere in which the US and the SU deal with the Arab-Israeli conflict." ${ }^{38}$ The rapprochement became the core of the new policies of the $\mathrm{US}^{39}$ and also SU. ${ }^{40}$ Consequently, the Cyprus problem and any conflict in the Middle East were now regarded within this framework.

33. J. Steel, Soviet Power: The Kremlin's Foreign Policy - Brezhnev to Andropov (New York, Simon and Schuster, 1983): 49.

34. Rogers, Telegram from the Department of State to the Embassy in Nicosia 40092, 19.3.1970: POL 27 CYP, box 2225, NARA.

35. Bureau of Intelligence and Research, Intelligence Note RNAN-7, February 17, 1972: POL 23-8 CYP XR POL 27-4 CYP/UN, box 2225, NARA; Johnson, Telegram from the Department of State to the Embassy in Athens 120297, July 3, 1972: POL 12 CYP XR POL 23 CYP, box 2224, NARA; Popper, Telegram from Embassy in Nicosia to the Department of the State 1299, June 28, 1972: POL 27 CYP XR POL 12 CYP XR POL CYP-GREECE, box 2224, NARA; Tasca, Telegram from the Embassy in Athens to the Department of the State 3737, July 4, 1972: POL 12 CYP XR POL 23 CYP, box 2224, NARA.

36. Background Paper: "Cyprus", July 1972: Lot 72D317, Entry 5037, Executive Secretariat: Briefing Books, 1958-1976: Visit of Secretary Rogerss to Greece, 7/1972, box 132, NARA.

37. Study Prepared by Interdepartmental Group for Near East and South Asia, Contingency Study for Cyprus, May 6, 1974, accessed May 21 2016, http://1.usa.gov/1s4jhml. 38. Ibid.

39. Kissinger outlined the central issues of American foreign policy in H. A. Kissinger, American Foreign Policy (New York: W. W. Norton and Co. Inc, 1974), 51-97.

40. A. A. Gromyko, Arms Limitation and Other Treaties, Vital Speeches of the Day, Speach Delivered before the General assembly of the United Nations, September 24, 1974. 


\section{The Greek Junta and Turkish Military in Cyprus}

Since 1971, the power struggle between the Greek Cypriots has continued and on July 1974 the Greek Junta overthrew Makarios. As a result, Turkey found the opportunity to act militarily in Cyprus.

The relations between President Makarios and the Greek Junta have been problematic from the beginning and the SU has been critical on foreign policy of Greece. On the other hand, the US had faced no serious problem with Makarios because of his non-aligned stance and his relations with the SU. After 1967 crisis when Makarios' moderate domestic policy and intercommunal talks began simultaneously rapprochement between Makarios and Washington also had started.

Then, why the US and the SU together did not stop the Greek coup and the Turkish military action? The first reason was the détente itself. Détente has given relative autonomy to the members of the alliances. Secondly, Secretary Kissinger as a realist did not take individuals into consideration very much. For him, the states and the balance of power between them were important. The new balance in Cyprus decreased the importance of Makarios as a political figure. On the other hand, Kissinger believed that the US had to support the Turks in maintaining their rights on the island. ${ }^{41}$ Nevertheless, Kissinger preferred the status quo and a situation where the Turks would not be provoked a situation that let the Soviet involvement. Although, it was détente period we have to remember that the Cold War was continuing and the confrontation between the SU and US has not ended.

For the Soviets the island's independent status had to be preserved and Greek junta in Cyprus stopped. Turkish-Soviet rapprochement was fruitful in this case. When Turkey gave assurance to the Soviet Union that it would not annex part of Cyprus, Moscow backed the Turkish action in Cyprus. For the Soviets, Turkey wanted to defend the Turkish Cypriots and restored the independence of Cyprus. ${ }^{42}$

On July 15, 1974 Kissinger aimed to decrease the Soviet suspicions of a NATO plot to subvert Cyprus" and had two telephone conversations with the Soviet Ambassador Dobrynin. ${ }^{43}$ Kissinger initially tried to appease the Ambassador and asked for coordinated actions with the Soviets. He guaranteed the US support to the existing constitution of the Republic of Cyprus. Dobrynin was pleased because this was the main concern of the SU and requested continuous information from the US. Kissinger promised to keep the Ambassador updated and told Dobrynin that the US had no unilateral interests

41. Minutes of Meeting of the Washington Special Actions Group, July 15, 1974, accessed May 21, 2016, http://1.usa.gov/1U8H25H.

42. M. Drousiotis, "Soviet Duplicity in the Cyprus Crisis", Cyprus Mail, last modified July 20, 2014, http://bit.ly/1OD1iYZ.

43. Minutes of Meeting of the Washington Special Actions Group, July 15, 1974, accessed May 21, 2016, http://1.usa.gov/1U8H25H. 
in Cyprus. Kissinger believed that the US and the SU could coordinate their actions and the Ambassador totally agreed with him. ${ }^{44}$

The aim of the United States was to avoid assuming a public stance which would commit it to any particular course of action. Also, the State Department believed that it was important that the US' friends and allies understood that any action in Cyprus which resulted in the overthrow of the Greek regime would open up the Eastern Mediterranean to Soviet meddling and exploitation. It would also invite an active Turkish intervention which would initiate an unpredictable course of events, difficult - if not impossible - to control, and would seriously damage Western interests. ${ }^{45}$

During the Turkish military action towards Cyprus on July 20, 1974, the American and Soviet naval units were positioned in the Eastern Mediterranean. ${ }^{46}$ The US and SU warships in the Mediterranean did not move because they did not want to give any sign of the military action related to Cyprus. $^{47}$

Clearly, détente shaped the policies of the superpowers in the 1970s. Nevertheless, one must not forget that détente was not the end of the Cold War but only a period of relative relaxation in great power relations. In this context, both sides were keen to prevent the Cyprus conflict from destroying their evolving relations. ${ }^{48}$ It was very important for the parties to refrain from actions and statements which might give the other superpower the impression that they were being cheated.

\section{Conclusion}

Cyprus was not a prior place that the SU specially had to deal with between the years 1964-1974. When it found an opportunity it tried to extend its influence in the region. Here, the level of the SU involvement depended on the level of the US threat that aimed to dissolve the unity of the SU. During this period, the SU tried to get benefit from the anti-West and rising nationalist feelings of the newly formed states and welcomed the inter-allied differences in NATO. When the Soviet-Turkish rapprochement started in 1964 the Soviets did not play a central role in the crisis and did not threaten to intervene. It

44 Transcript of Telephone Conversation between Kissinger and Dobrynin, July 15, 1974, accessed May 21, 2016, http://1.usa.gov/1XMkdrx; Transcript of Telephone Conversation between Kissinger and Dobrynin, July 15, 1974, accessed May 21, 2016, http://1.usa.gov/ 25hjNPx.

45 Minutes of Meeting of the Washington Special Actions Group, July 18, 1974, accessed July 21, 2016, http://1.usa.gov/1s4jhTh.

46. Records of Joseph Sisco, (1951-1976), July 20, 1974, Chronology of Cyprus Issue and Other Documents, Entry 5405, box 24, NARA.

47. Minutes of Meeting of the Washington Special Actions Group, July 15, 1974, accessed May 21, 2016, http://1.usa.gov/1U8H25H.

48. Study Prepared by Interdepartmental Group for Near East and South Asia, Contingency Study for Cyprus, May 6, 1974, accessed May 21 2016, http://1.usa.gov/ 1sMG9HJ. 
continued to support the independence of Cyprus but its support was now lukewarm.

In the early 1970's, the SU and the US began to understand the growing interdependence of nations. They identified their common interests and created some sort of rules of behavior. The rules included the view that the superpowers would not interfere in the domestic affairs and not even in the affairs of the sphere of interest of the other party. The growing pragmatism was a central element of détente.

While the SU continued to support independent Cyprus in 1974, after the second military operation of Turkey, it became more suspicious on Turkey's plan and mediated Makarios returning to the rule. Yet, as the Cyprus issue was not vital to the SU's interests it has let the problem to be solved in the UN.

\section{Bibliography}

Primary Sources: (US National Archives and Record Administration)

Background Paper: "Cyprus", July 1972: Lot 72D317, Entry 5037, Executive Secretariat: Briefing Books, 1958-1976: Visit of Secretary Rogerss to Greece, 7/1972, box 132, NARA.

Belcher, Telegram from the Embassy in Nicosia to the Department of State 1265, May 22, 1964: POL 23-8 CYP, box 2084, NARA.

Belcher, Airgram from the Embassy in Nicosia to the Department of State A-249, June 2, 1967: POL 1 CYP-US, box 2029, NARA.

Belcher, Telegram from the Embassy in Nicosia to the Department of State 1249, February 24, 1967: POL 27 CYP, box 2023, NARA.

Bureau of Intelligence and Research, Intelligence Note RNAN-7, February 17, 1972: POL 23-8 CYP XR POL 27-4 CYP/UN, box 2225, NARA.

Hughes, Memorandum for the Cyprus Working Group, "Contingency Planning on Cyprus-Assessment of Likely Soviet Action", November 22, 1967: Lot 70D46, Entry 5191, Office of the Executive Secretariat: Cyprus Crisis Files, 1967: Working Papers, box 3, NARA.

Hughes, Intelligence Note to Rusk, "Soviet Government Criticizes Athens and Greek Cypriot Regimes, Is Soft on Turks", November 22, 1967: POL 27 CYP, box 2025, NARA.

Johnson, Telegram from the Department of State to the Embassy in Athens 120297, July 3, 1972: POL 12 CYP XR POL 23 CYP, box 2224, NARA.

Katzenbach, Telegram from the Department of State to the Embassy in Paris 98890, December 8, 1966: DEF 12-5 CYP, box 1620, NARA.

Katzenbach, Telegram from the Department of State to the Embassy in Athens 101135, December 12, 1966: POL 27 CYP XR DEF 19-6 CZECH-CYP, box 2100, NARA.

Katzenbach, Telegram from the Department of State to the Embassy in Paris 104909, December 19, 1966: POL 27 CYP, box 2100, NARA.

Kohler, Telegram from the Embassy in Moscow to the Department of State 2287, February 6, 1965: POL 27 CYP, box 2095, NARA.

Minutes of Meeting of the Washington Special Actions Group, July 15, 1974. Accessed May 21, 2016. http://1.usa.gov/1U8H25H. 
Minutes of Meeting of the Washington Special Actions Group, July 18, 1974. Accessed July 21, 2016. http://1.usa.gov/1s4jhTh.

Paper prepared by the Planning and Coordination Staff at the State Department: Briefing for the Under Secretary: "Foreign Affairs Policies and Problems", August 28, 1970: Executive Secretariat Briefing Books, 1958-1976, Lot 72D170 Committee to Facil Travel, 5/1970, box 49, NARA.

Popper, Telegram from Embassy in Nicosia to the Department of the State 1299, June 28, 1972: POL 27 CYP XR POL 12 CYP XR POL CYP-GREECE, box 2224, NARA.

Records of Joseph Sisco, (1951-1976), July 20, 1974, Chronology of Cyprus Issue and Other Documents, Entry 5405, box 24, NARA.

Rogers, Telegram from the Department of State to the Embassy in Nicosia 40092,

19.3.1970: POL 27 CYP, box 2225, NARA.

Rusk, Telegram from the Department of State to the Embassy in Nicosia (384), January 31, 1964, POL 23-8 CYP, box 2078, NARA.

Rusk, Telegram from the Department of State to the Embassy in Athens 1179, March 18, 1965: POL 27 CYP, box 2096, NARA.

Rusk, Telegram from the Department of State to the Embassy in Nicosia 860, May 20, 1964: POL 23-8 CYP, box 2084, NARA.

Rusk, Telegram from the Department of State to the Embassy in Ankara 143499, February 24, 1967: POL 27 CYP XR DEF 19-6 CZECH-CYP, box 2023, NARA.

Study Prepared by Interdepartmental Group for Near East and South Asia, Contingency Study for Cyprus, May 6, 1974. Accessed May 21, 2016. http://1.usa.gov/1s4jhml.

Talbot, Memorandum from the Embassy in Athens to the Department of State (Ball), "Review of U.S. Cyprus Policy", December 31, 1964: POL 27 CYP, box 2094, NARA.

Talbot, Telegram from the Embassy in Athens to the Department of State 3093, December 16, 1966: POL 27 CYP, box 2100, NARA.

Tasca, Telegram from the Embassy in Athens to the Department of the State 3737, July 4, 1972: POL 12 CYP XR POL 23 CYP, box 2224, NARA.

Transcript of Telephone Conversation between Kissinger and Dobrynin, July 15, 1974. Accessed May 21, 2016. http://1.usa.gov/1XMkdrx.

Transcript of Telephone Conversation between Kissinger and Dobrynin, July 15, 1974. Accessed May 21, 2016. http://1.usa.gov/25hjNPx.

Wilkins, F. Telegram from the Embassy in Nicosia to the Department of State, September 28, 1960. Accessed May 21, 2016. http://1.usa.gov/1YQXyZx.

\section{Secondary Sources}

Adams, T. W. and Cottrell A. J. Cyprus between East and West, Baltimore: The John Hopkins Press, 1968.

Bolukbasi, S. The Superpowers and the Third World: Turkish American Relations and Cyprus. Langham: University Press of America, 1988.

Brands, H. W. The United States in the World: A History of American Foreign Policy, Vol. II. Boston: Houghton Mifflin Company, 1994.

Breznev, L. "The USSR's Foreign Policy: Peace is Indivisible". Vital Speeches of the Day, Speach delivered at Tashkent, September 25, 1973.

Combs, J. A. The History of American Foreign Policy since 1900, Vol. II. New York: McGraw-Hill Publication Company, 1986. 
Drousiotis, M. "Soviet Duplicity in the Cyprus Crisis." Cyprus Mail, last modified July 20, 2014, http://bit.ly/1OD1iYZ.

Encyclopadia Britannica Online, s. v. "United Arab Republic (U.A.R.)". Accessed February 6, 2016. http://bit.ly/1U3ZmKi.

Evans, G. and J. Newnham. Dictionary of International Relations. London: Penguin Books, 1998.

Fırat M. M. 1960-71 Arası Türk Dış Politikası ve Kıbrıs Sorunu [Turkish Foreign Policy and Cyprus Problem between 1960 and 1971]. Ankara: Siyasal Kitabevi, 1997.

Gromyko A. A. and V. M. Khvostov. History of Soviet Foreign Policy (1945-1970). Moscow: Progress Publishers, 1974.

Gromyko, A. A. Arms Limitation and Other Treaties, Vital Speeches of the Day. Speach delivered before the General assembly of the United Nations, September 24. 1974.

Kissinger, H. A. Diplomacy. New York: Touchstone-Simon \& Schuster, 1995.

Kissinger, H. A. American Foreign Policy. New York: W. W. Norton and Co. Inc: 1974.

Khrushchev, N. Speech to $20^{\text {th }}$ Congress of the C.P.S.U., 24-25.02.1956. Accessed October 2, 2015, http://bit.ly/1P13XiY.

Lerche, C. O. "The Crisis in American World Leadership." The Journal of Politics, 28, no. 2 (1966): 309-310.

McLean, I. The Concise Oxford Dictionary of Politics. Oxford: Oxford University Press, 1996.

Sander, O. Türk-Amerikan İlişkileri (1947-1964) [Turkish-American Relations]. Ankara: Ankara Üniversitesi Siyasal Bilgiler Fakültesi Yayınları, 1979.

Steel, J. Soviet Power: The Kremlin's Foreign - Brezhnev to Andropov. New York: Simon and Schuster, 1983.

Tellal, E. "Relations with the USSR." In, Turkish Foreign Policy: Facts and Analyses with Documents, edited by B. Oran. Salt Lake City: The University of Utah Press, 2010.

Stergiou, A. "Soviet Policy toward Cyprus." The Cyprus Review 19, no. 2 (2007): 83106.

Tellal, E. "Sovyet Dış Politikası ve Gromiko" ["Soviet Foreign Policy and Gromyko"]. Ankara Universitesi SBF Dergisi, 62, no. 3 (2007): 360.

Tellal, E. "Relations with the USSR." In Turkish Foreign Policy: Facts and Analyses with Documents, edited by B. Oran. Salt Lake City: The University of Utah Press, 2010. 
